\title{
UTJECAJ MONETARNE I FISKALNE POLITIKE NA INDUSTRIJSKU PROIZVODNJU U REPUBLICI HRVATSKOJ
}

\begin{abstract}
Petra Palić ${ }^{9}$
UDC / UDK: 336.74:338.23:336.2:338.45(497.5)

JEL classification / JEL klasifikacija: C23, E23, E63

DOI: https://doi.org/10.22598/pi-be/2021.15.1.63

Preliminary communication / Prethodno priopćenje

Received / Primljeno: October 28, 2020 / 28. listopada 2020.

Accepted for publishing / Prihvaćeno za tisak: February 26, 2021 / 26. veljače 2021.

\section{Sažetak}

$U$ radu se istražuje utjecaj monetarne $i$ fiskalne politike na industrijsku proizvodnju u Republici Hrvatskoj. Brojna inozemna i domaća istraživanja nastojala su procijeniti ovaj odnos s ciljem pružanja preporuke nositeljima ekonomske politike. Koristeći panel model, ispituje se kako relativne proizvođačke cijene, državna potrošnja, osobna potrošnja, kamatne stope, realni efektivni tečaj, te strana potražnja utječu na 23 komponente industrijske proizvodnje prema stupnju tehnološkog intenziteta. Analiza je provedena na tromjesečnim podacima za razdoblje od prvoga tromjesečja 2000. do posljednjeg tromjesečja 2015. godine. Provedena je $i$ analiza utjecaja monetarne $i$ fiskalne politike na industrijsku proizvodnju za razdoblje prije i nakon nastupanja gospodarske krize u Republici Hrvatskoj. Rezultati empirijskog dijela istraživanja u skladu su s domaćom i stranom literaturom te je pronađena statistički signifikantna veza utjecaja monetarne i fiskalne politike na industrijsku proizvodnju.
\end{abstract} panel analiza.

Ključne riječi: industrijska proizvodnja; fiskalna politika; monetarna politika;

\section{UVOD}

Cilj ovog istraživanja je odrediti utjecaj makroekonomskih politika, odnosno monetarne i fiskalne politike na industrijsku proizvodnju u Republici Hrvatskoj. Europska unija prepoznaje važnost industrijske proizvodnje za razvoj i rast gospodarstva i nastoji povećati konkurentnost europske industrije kako bi se osiguralo zadržavanje uloge pokretača održivog razvoja i zapošljavanja koju industrijska proizvodnja ima u Europi.

${ }^{9}$ Dr. sc. Petra Palić, docentica, Hrvatsko katoličko sveučilište, Ilica 242, Zagreb, Hrvatska, E-mail: petra.palic@unicath.hr 
Svjetska gospodarska kriza naglasila je važnost uloge Europske komisije u praćenju industrijske proizvodnje, kroz politike i aktivnosti koje imaju za cilj povećati udio industrijske proizvodnje u gospodarstvu i doprinijeti inovativnom razvoju. Prema Europskoj komisiji, na nacionalnoj razini i na razini Europske unije potrebna je modernizacija, adekvatni programi za industriju, posebice za mala i srednja poduzeća, te su potrebna daljnja istraživanja na razini Europske unije kako bi se podržala industrijska konkurentnost. Značaj same proizvodnje proizlazi iz činjenice da je nositelj inovacija, istraživanja i razvojnih aktivnosti koje se na kraju prelijevaju i na ostale sektore te rezultiraju povećanju produktivnosti (Tkalec i Vizek, 2009). Osim industrije specifičnih čimbenika i industrijske politike, makroekonomski uvjeti su najutjecajniji pokretači rasta proizvodnje (Tkalec i Vizek, 2009:Europska komisija, 2009a).

Što se tiče industrijske proizvodnje u Hrvatskoj, prema podacima Državnog zavoda za statistiku (DZS), industrijska je proizvodnja u 2016. godini prema kalendarski prilagođenim indeksima ubrzala godišnji rast, a ujedno je prema podacima Eurostata bila i među članicama Europske unije s najvećim rastom na godišnjoj razini. Pojačani trend inozemne potražnje i oporavak domaće potražnje pozitivno utječu na industrijsku proizvodnju. Međutim, osim očekivanog pozitivnog utjecaja povećane potražnje na industrijsku proizvodnju, od interesa je, kako za akademsku zajednicu, tako i za nositelje ekonomske politike, kvantificirati i utjecaje monetarne i fiskalne politike na industrijsku proizvodnju. U tom smislu, proizlaze glavna istraživačka pitanja ovog rada koja se temelje na testiranju utjecaja kamatnih stopa, realnog efektivnog tečaja, strane potražnje, državne potrošnje, potrošnje kućanstva i relativnih proizvođačkih cijena na industrijsku proizvodnju. Za procjenu su korištena tri statička panel modela te je sama analiza provedena na kvartalnim podacima od 2000. do 2015. godine. Zbog značajne promjene ekonomskog okruženja u jeku velike gospodarske krize 2009. godine, procjenjuje se i utjecaj makroekonomskih odrednica na industrijsku proizvodnju prije i nakon krize, gdje se kao točka diskontinuiteta uzima treći kvartal 2009. godine kada je počela kriza u Hrvatskoj.

\section{PREGLED ISTRAŽIVANJA}

Akademsku zajednicu oduvijek je zanimalo što utječe na rast gospodarstva te je pritom istraživano i testirano na koji način pojedine makroekonomske odrednice utječu na rast gospodarstva. Kormendi i Meguire (1985) te Barro (1991) pokazali su u svojim istraživanjima kako različite makroekonomske varijable objašnjavaju rast gospodarstva. Kormendi i Meguire (1985) su kao uzorak koristili četrdeset i sedam zemalja za razdoblje od četrdeset godina. Pritom su našli negativnu korelaciju između ekonomskog rasta i ponude novca. Levine i Renelt (1992) vodili su se saznanjima do kojih su došli Kormendi i Meguire (1985) te Barro (1991) te su potvrdili da investicije u velikoj mjeri utječu na rast gospodarstva. Fischer (1993) je pokazao da je rast gospodarstva negativno povezan s inflacijom, velikim proračunskim deficitima i deviznim tržištima. Identifikacijom kanala učinka makroekonomske politike prema rastu došao je do zaključka kako inflacija utječe na smanjenje investicija i produktivnosti što negativno utječe na sami rast 
gospodarstva. Proračunski deficit također djeluje na pad akumulacije kapitala i produktivnosti. Campa i Goldberg (1997) usredotočeni su na utjecaj makroekonomskih politika na industrijsku poroizvodnju. Pritom analiziraju kako promjene u tečaju i trgovinskoj politici utječu na industrijsku proizvodnju Sjedinjenih Država, Kanade, Japane i Velike Britanije.

Bruce i Turnovsky (1999) dizajnirali su model korištenjem fiskalnih pokazatelja kao što su porezne stope i državna potrošnja. Pritom su zaključili da smanjena uključenost države na tržištu djeluje pozitivno i potiče rast proizvodnje. U literaturi korak dalje idu Adam i sur. (2001) analizirajući četrdeset i pet zemalja u razdoblju od 1970. do 1999. godine. Istražujući odnos između fiskalnog deficita i rasta, pronašli su specifični prag proračunskog deficita od 1,5 posto BDP-a. Preporuka za vođenje fiskalne politike odnosila se na smanjenje deficita do ove razine kako bi se iscrpio potencijalni rast.

Primjerice, Kutu i sur. (2017) su analizirali utjecaj monetarne politike na rast industrijskog sektora u Kini za razdoblje od 1994. do 2013. godine. Prema dobivenim rezultatima empirijske analize, zaključili su kako monetarna politika u kratkom roku značajno utječe na rast industrijskog sektora. S druge strane, Ezeaku i sur. (2018) procijenili su učinak kanala monetarne transmisije na industrijsku proizvodnju u Nigeriji za vremensko razdoblje od 1981. do 2014. godine. Zaključili su kako kanali kredita, kamatnih stopa i tečaja imaju negativan učinak na realni rast proizvodnje u kratkom i dugom roku. Također, utjecaj monetarne politike na industrijsku proizvodnju u Nigeriji za razdoblje od 1960. do 2015. analizirao je Shodande (2019). Na temelju ekonometrijske analize došao je do zaključka kako bi donositelji politika trebali koristiti i konvencionalnu i nekonvencionalnu monetarnu politiku za ubrzavanje rasta industrijske proizvodnje i povećanje ekonomskog rasta.

Što se tiče empirijske literature u Hrvatskoj, Erjavec i sur. (1999) koristeći vektorsku autoregresiju (VAR) analiziraju utjecaj monetarno-kreditnih agregata na realni sektor. Pritom, koriste industrijsku proizvodnju kao mjeru stvarne gospodarske aktivnosti, te u VAR model uključuju ponudu novca, potrošačke cijene, domaću kreditnu aktivnost i nezaposlenost. Pokazali su kako novčana masa ne utječe na industrijsku proizvodnju, dok domaća kreditna aktivnost lagano nestaje nakon jedne godine. Također, Ćorić i sur. (2015) koristeći vektorsku autoregresiju (VAR) analiziraju utjecaj monetarne i fiskalne politike u postizanju glavnih ciljeva ekonomske politike, odnosno postizanje gospodarskog rasta i stabilnosti cijena u Hrvatskoj za razdoblje od 2004. do 2012. godine. Zaključili su kako koordinirane mjere monetarne i fiskalne politike mogli postići oba cilja, odnosno mogu potaknuti gospodarski rast bez da se pritom ugrozi stabilnost cijena. Detaljnu ekonometrijsku analizu monetarnog prijenosa u Republici Hrvatskoj daje Vizek (2008) i dolazi do zaključka kako regulacija novčane mase i deviznog tečaja utječe na realni sektor, dok s druge strane monetarna politika ne utječe na realnu ekonomsku aktivnost kanalom kamatne stope.

Tkalec i Vizek (2009) daju najdetaljniju i sveobuhvatnu analizu utjecaja makroekonomskih politika na industrijsku proizvodnju u Republici Hrvatskoj. Rezultati njihove empirijske analize sugeriraju da industrijska proizvodnja općenito najviše reagira na promjene u fiskalnoj politici, odnosno na državnu potrošnju i fiskalni deficit. S druge strane, monetarna politika nema preveliki utjecaj na industrijsku proizvodnju. Rezultati 
pokazuju kako promjena kamatnih stopa ima utjecaja samo na nekoliko proizvodnih industrija, dok reakcija proizvodnih industrija na promjenu realnog tečaja znatno ovisi o razini tehnološkog intenziteta pojedine industrije. Autorice dolaze do zaključka kako trajni rast i razvoj industrijske proizvodnje mora biti temeljen na mjerama fiskalne politike u kombinaciji s ostalim mjerama poput promicanja inovacija, stranih izravnih ulaganja, podupiranja konkurencije unutar same industrijske proizvodnje zajedno $\mathrm{s}$ dodjelama subvencija, promjenama u obrazovnom sustavu i promjenama u energetskoj politici.

Ovo istraživanje doprinosi postojećoj literaturi u kontekstu provedene empirijske analize za komponente industrijske proizvodnje grupirane prema stupnju tehnološkog intenziteta. Naime, u ovome radu istražuje se utjecaj makroekonomskih politika na dvadeset i tri komponente industrijske proizvodnje u Republici Hrvatskoj. Provedena panel analiza također doprinosi postojećoj literaturi u aspektu metodologije. Također, bitna razlika i doprinos postojećoj literaturi koji se u ovom radu ističe je činjenica da je provedena empirijska analiza za dva razdoblja, odnosno razdoblje prije službenog početka gospodarske krize u Republici Hrvatskoj i razdoblje nakon nastanka. Ovom podjelom na dva razdoblja omogućena je procjena utjecaja krize na odnose između monetarne i fiskalne politike te industrijske proizvodnje u Republici Hrvatskoj.

\section{PODACI I METODOLOŠKI PRISTUP}

$\mathrm{U}$ svrhu procjene utjecaja monetarne i fiskalne politike na industrijsku proizvodnju za Hrvatsku korišteni su kvartalni podaci u razdoblju od 2000. do 2015. godine. Pritom su procijenjena tri panel modela kako bi se modelirale interakcije makroekonomskih fundamenata na komponente industrijske proizvodnje prema tehnološkom intenzitetu. U svrhu mjerenja proizvodne aktivnosti korišten je indeks industrijske proizvodnje za 23 komponente industrijske proizvodnje (IND_PRO). Kao kontrolna varijabla korištene su relativne proizvođačke cijene po komponentama (REL_PPI). Također, korištene su makroekonomske odrednice poput potrošnje kućanstva (C), strane potražnje koja je procijenjena na temelju četiri najvećih trgovinskih partnera Republike Hrvatske (GDP_F), državne potrošnje (G), realnog tečaja (REER) i kamatne stope (MM_IR).

Podaci za indeks industrijske proizvodnje prikupljeni su iz priopćenja DZS-a od 2000. do 2015. godine. Tablica 1 prikazuje podjelu komponenti industrijske proizvodnje prema tehnološkom intenzitetu, te su prema toj podjeli i konstruirani statički panel modeli za daljnju analizu. Od Eurostata su preuzeti početni podaci za stranu potražnju koja je procijenjena od strane autora za četiri najveća trgovinska partnera RH (Slovenija, Italija, Austrija i Njemačka), potrošnju kućanstva, realni tečaj i relativne proizvođačke cijene, dok su podaci za kamatnu stopu preuzeti od Hrvatske narodne banke. Podaci za državnu potrošnju preuzeti od Ministarstva financija.

Grafički prikazi podataka za ukupnu industrijsku proizvodnju, ukupne relativne proizvođačke cijene (REL_PPI), domaću potrošnju (C), realni tečaj (REER), stranu potražnju (GDP_F), državnu potrošnju (G) i kamatne stope (MM_IR) mogu se vidjeti na 
slici 1. Za potrebe procjene modela, sve varijable osim kamatnih stopa su logaritmirane i ukoliko je potrebno deflacionirane.

Tablica 1. Komponente industrijske proizvodnje prema tehnološkom intenzitetu

\begin{tabular}{|l|l|l|}
\hline $\begin{array}{c}\text { Visoko-tehnološke } \\
\text { komponente industrijske } \\
\text { proizvodnje }\end{array}$ & $\begin{array}{c}\text { Srednje-tehnološke } \\
\text { komponente } \\
\text { industrijske } \\
\text { proizvodnje }\end{array}$ & \multicolumn{1}{|c|}{$\begin{array}{c}\text { Nisko-tehnološke } \\
\text { komponente industrijske } \\
\text { proizvodnje }\end{array}$} \\
\hline $\begin{array}{l}\text { Kemikalije i kemijski } \\
\text { proizvodi }\end{array}$ & Koks i naftni proizvodi & Hrana \\
\hline Farmaceutski proizvodi & $\begin{array}{l}\text { Proizvodi od gume i } \\
\text { plastike }\end{array}$ & Piće \\
\hline $\begin{array}{l}\text { Računala električni i } \\
\text { optički proizvodi }\end{array}$ & $\begin{array}{l}\text { Ostali nemetalni } \\
\text { mineralni proizvodi }\end{array}$ & $\begin{array}{l}\text { Tiskanje i umnožavanje } \\
\text { snimljenih zapisa }\end{array}$ \\
\hline $\begin{array}{l}\text { Proizvodnja električne } \\
\text { opreme }\end{array}$ & Metali & Tekstil \\
\hline Strojevi i uređaji & $\begin{array}{l}\text { Gotovi metalni } \\
\text { proizvodi }\end{array}$ & Odjeća \\
\hline $\begin{array}{l}\text { Motorna vozila prikolice i } \\
\text { poluprikolice }\end{array}$ & & Koža i srodni proizvodi \\
\hline Ostala prijevozna sredstva & & $\begin{array}{l}\text { Prerada drva i proizvodi od } \\
\text { drva }\end{array}$ \\
\hline & Proizvodnja papira \\
\hline & Duhanski proizvodi \\
\hline & Proizvodnja namještaja \\
\hline & $\begin{array}{l}\text { Ostala prerađivačka } \\
\text { industrija }\end{array}$ \\
\hline
\end{tabular}

Izvor: Eurostat. 
Slika 1. Prikaz korištenih serija podataka c

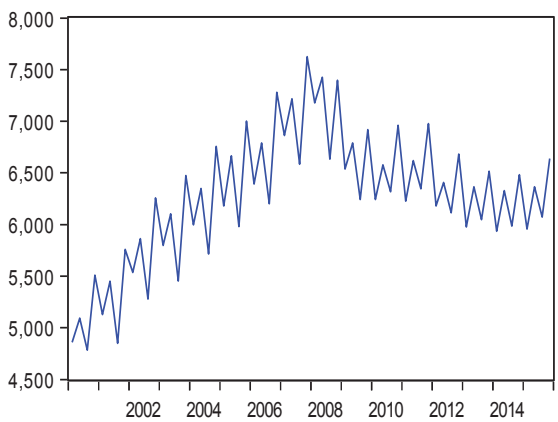

GDP

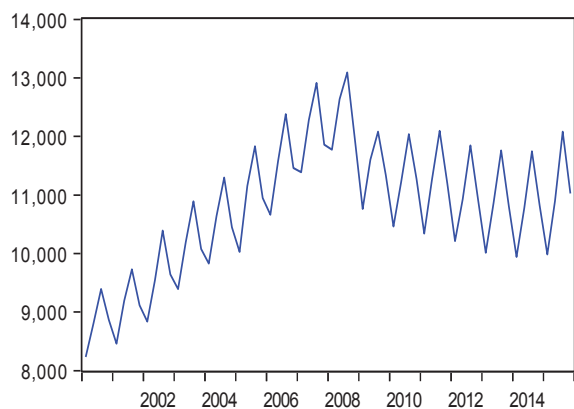

IND_PRO

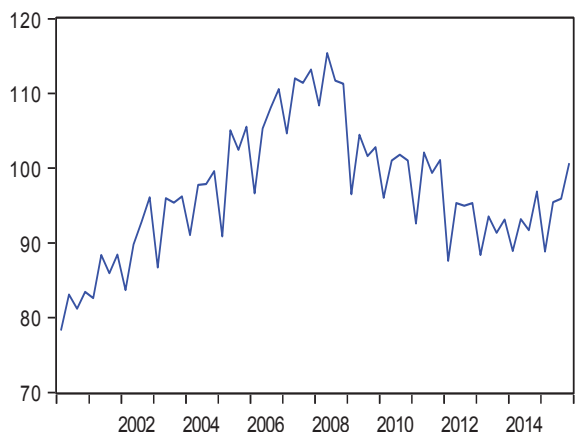

G

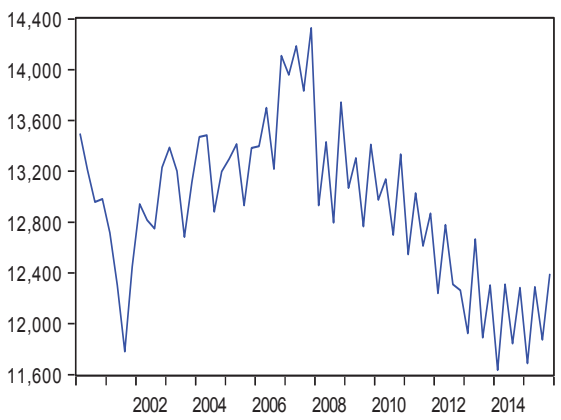

GDP_F

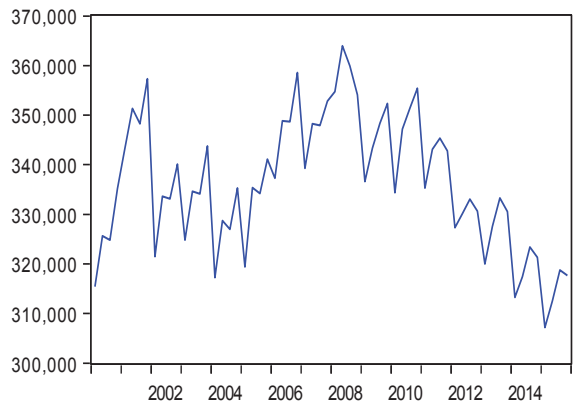

MM_IR

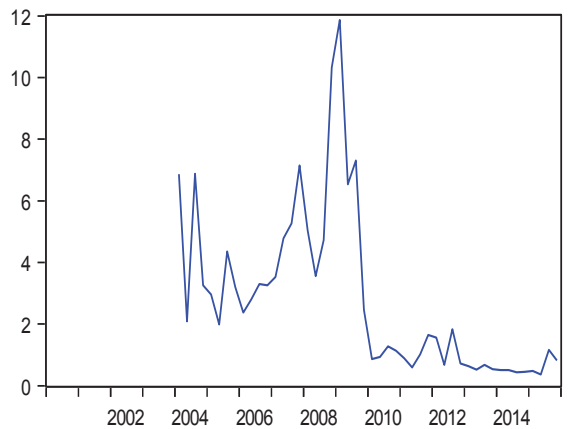


REER

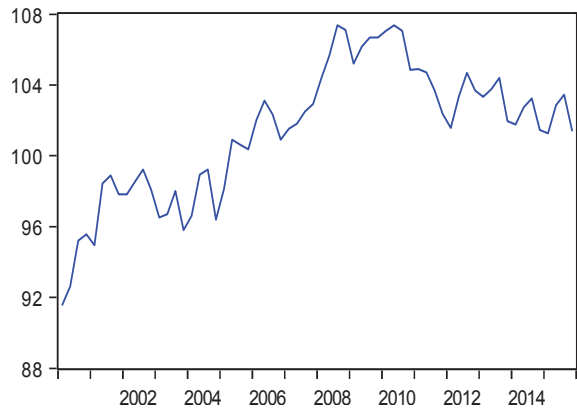

REL_PPI

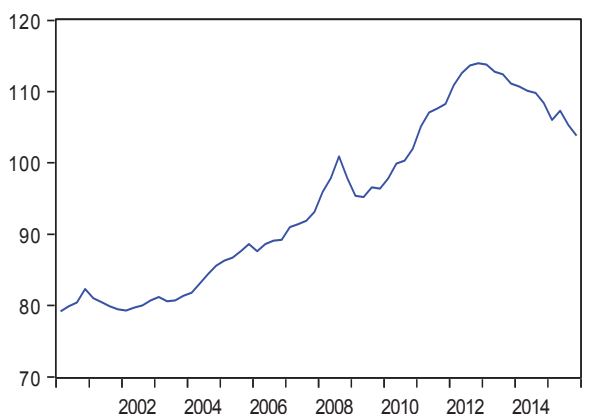

Izvor: Eurostat, DZS i Ministarstvo financija.

\section{REZULTATI ANALIZE}

Model kojim se procjenjuje utjecaj monetarne i fiskalne politike na industrijsku proizvodnju dan je jednadžbom:

$$
I N D \_P R O_{i t}=\alpha+\beta_{1} R E L \_P P I_{i t}+\beta_{2} C_{i t}+\beta_{3} G_{i t}+\beta_{4} G D P \_F_{i t}+\beta_{5} R E E R_{i t}+\beta_{6} M M_{-} I R i t+\varepsilon_{i t}
$$

Pritom (IND_PRO) predstavlja indeks industrijske proizvodnje za 23 komponente industrijske proizvodnje, dok su relativne proizvođačke cijene po komponentama (REL_PPI) korištene kao kontrolna varijabla. Također, korištene su makroekonomske odrednice poput potrošnje kućanstva $(\mathrm{C})$, strane potražnje koja je procijenjena na temelju četiri najvećih trgovinskih partnera Republike Hrvatske (GDP_F), državne potrošnje (G), realnog tečaja (REER) i kamatne stope (MM_IR). Procijenjena su tri statička panel modela specificirana gore navedenom jednaď̌bom prema tehnološkom intenzitetu komponenti industrijske proizvodnje kako bi se modelirale interakcije makroekonomskih fundamenata na industrijsku proizvodnju. Rezultati empirijske analize, odnosno utjecaji monetarne i fiskalne politike na industrijsku proizvodnju prema tehnološkom intenzitetu komponenti industrijske proizvodnje za razdoblje od 2000. do 2015. godine prikazani su u tablicama 2. i 3. Pritom su u tablici 2. dani rezultati fiksnih efekata dok su u tablici 3. dani rezultati slučajnih efekata panel analize. Pritom je bilo nužno testirati i odlučiti o korištenju fiksnih ili slučajnih efekata, pri čemu se primjenjuje Hausmanov test specifikacije. Hausmanov test, odnosno u nultu hipotezu ovog testa ulazi se $\mathrm{s}$ pretpostavkom da su i OLS i GLS metoda konzistentne, ali da pritom OLS nije efikasan, a u alternativnoj je OLS konzistentan, ali GLS nije. U nultoj hipotezi stoji tvrdnja da su oba procjenitelja konzistentna, ali model nije efikasan, a u alternativnoj da je konzistentan i efikasan, ali je nekonzistentan. Obzirom da se nulta hipoteza ne može odbaciti za sve tri procjene utjecaja monetarnih i fiskalnih politika na komponente industrijske proizvodnje 
grupirane prema tehnološkom intenzitetu dolazi se do zaključka kako je model sa slučajnim efektom prikladniji za procjenu (Asteriou \& Hall, 2007.).

Tablica 2. Panel analiza utjecaja monetarnih i fiskalnih mjera na industrijsku proizvodnju za razdoblje od 2000. do 2015. godine (fixed effects)

\begin{tabular}{|c|c|c|c|}
\hline \multicolumn{4}{|c|}{$\begin{array}{c}\text { Zavisna varijabla } \\
\text { IND_PPI }\end{array}$} \\
\hline Kontrolne varijable & $\begin{array}{c}\text { visoko- } \\
\text { tehnološke } \\
\text { komponente } \\
\text { industrijske } \\
\text { proizvodnje }\end{array}$ & $\begin{array}{c}\text { srednje- } \\
\text { tehnološke } \\
\text { komponente } \\
\text { industrijske } \\
\text { proizvodnje }\end{array}$ & $\begin{array}{c}\text { nisko } \\
\text { tehnološke } \\
\text { komponente } \\
\text { industrijske } \\
\text { proizvodnje }\end{array}$ \\
\hline REL PPI & $1,01(0,11)$ *** & $-0,69(0,08) * * *$ & $-1,29(0,17) * * *$ \\
\hline $\mathrm{C}$ & $0,50(0,21) * *$ & $0,16(0,41)$ & $-0,72(0,19) * * *$ \\
\hline $\mathrm{G}$ & $1,02(0,42) * *$ & $1,46(0,3) * * *$ & $1,73(0,37) * * *$ \\
\hline GDP F & $0,64(0,42)$ & $0,14(0,31)$ & $0,73(0,38) *$ \\
\hline REER & $-0,20(0,56)$ & $0,16(0,41)$ & $-0,87(0,51) *$ \\
\hline MM_IR & $0,13(0,01) * *$ & $0,02(0,004) * * *$ & $0,01(0,01) * *$ \\
\hline \multicolumn{4}{|l|}{ Diagnostics } \\
\hline Number of observations & 427 & 305 & 672 \\
\hline Within $R$-squared & 0,3424 & 0,3904 & 0,131 \\
\hline Between $R$-squared & 0,0073 & 0,7852 & 0,6715 \\
\hline Overall R-squared & 0,281 & 0,4037 & 0,2132 \\
\hline
\end{tabular}

Napomena: $* * *$ označava signifikantnost pri $1 \%$, ** pri $5 \%$, a * pri $10 \%$.

Izvor: izrada autora prema podacima DZS-a, Eurostata i Ministarstva financija.

Tablica 3. Panel analiza utjecaja monetarnih i fiskalnih mjera na industrijsku proizvodnju za razdoblje od 2000. do 2015. godine (random effects)

\begin{tabular}{|l|l|l|l|}
\hline \multicolumn{4}{|c|}{$\begin{array}{c}\text { Zavisna varijabla } \\
\text { IND_PPI }\end{array}$} \\
\hline Kontrolne varijable & $\begin{array}{c}\text { visoko-tehnološke } \\
\text { komponente } \\
\text { industrijske } \\
\text { proizvodnje }\end{array}$ & $\begin{array}{c}\text { srednje- } \\
\text { tehnološke } \\
\text { komponente } \\
\text { industrijske } \\
\text { proizvodnje }\end{array}$ & $\begin{array}{c}\text { nisko } \\
\text { tehnološke } \\
\text { komponente } \\
\text { industrijske } \\
\text { proizvodnje }\end{array}$ \\
\hline REL_PPI & $1,01(0,11) * * *$ & $-0,67(0,07) * * *$ & $-1,37(0,17) * * *$ \\
\hline C & $0,50(0,21)^{* *}$ & $0,16(0,16)$ & $-0,74(0,19)^{* * *}$ \\
\hline G & $1,02(0,42) * *$ & $1,46(0,3) * * *$ & $1,76(0,37)^{* * *}$ \\
\hline GDP_F & $0,65(0,42)$ & $0,14(0,31)$ & $0,74(0,38) * *$ \\
\hline REER & $-0,20(0,56)$ & $0,16(0,41)$ & $-0,92(0,51) *$ \\
\hline
\end{tabular}




\begin{tabular}{|l|l|l|l|}
\hline MM_IR & $0,13(0,01) * *$ & $0,02(0,004) * * *$ & $0,01(0,01) * *$ \\
\hline Diagnostics & & & \\
\hline Number of observations & 427 & & \\
\hline Within $R$-squared & 0,3424 & 305 & 672 \\
\hline Between $R$-squared & 0,0073 & 0,3904 & 0,1308 \\
\hline Overall R-squared & 0,2812 & 0,7852 & 0,6715 \\
\hline Hausman test & chi2 & 0,4038 & 0,2151 \\
& Prob $>$ chi2 $=0,9982$ & $\begin{array}{l}\text { chi2(6) }=0,32 \\
\text { Prob }>\text { chi2 }= \\
0,9994\end{array}$ & $\begin{array}{l}\text { chi2 }(6)=4,65 \\
\text { Prob }>\text { chi2 }= \\
0,5896\end{array}$ \\
\hline
\end{tabular}

Napomena: $* * *$ označava signifikantnost pri $1 \%$, ** pri $5 \%$, a $*$ pri $10 \%$.

Izvor: izrada autora prema podacima DZS-a, Eurostata i Ministarstva financija.

Prema prijašnjim istraživanjima može se očekivati da ekspanzivna monetarna politika povećava proizvodnju, a da je ekspanzivna fiskalna politika smanjuje (Tkalec i Vizek 2009). Rezultati procijenjenog modela za visoko-tehnološke komponente industrijske proizvodnje pokazuju da je za promatrano razdoblje od 2000. do 2015. godine utjecaj makroekonomskih odrednica, odnosno monetarne i fiskalne politike na visoko-tehnološke komponente industrijske proizvodnje u Hrvatskoj signifikantan. Naime, na visoko-tehnološke komponente industrijske proizvodnje za ovaj period značajno pozitivno utječe promjena relativnih proizvođačkih cijena što je bilo i očekivano. Od varijabli karakterističnih za fiskalnu politiku, državna potrošnja i potrošnja kućanstva imaju pozitivan utjecaj na industrijsku proizvodnju s razinom signifikantnosti od 5 posto. Međutim strana potražnja nema značajan utjecaj na visoko-tehnološke komponente industrijske proizvodnje, ali je predznak u skladu s teorijom, odnosno povećanje strane potražnje dovodi do povećanja visoko-tehnoloških komponenta industrijske proizvodnje. Što se tiče monetarnih varijabli, kamatne stope pokazale su se značajnima s pozitivnim predznakom na razini od pet posto signifikantnosti, dok relativan tečaj s očekivanim negativnim predznakom ne utječe značajno na visoko-tehnološke komponente industrijske proizvodnje. Sukladno rezultatima, može se zaključiti kako najveći pozitivni efekt na visoko-tehnološke komponente industrijske proizvodnje imaju relativne proizvođačke cijene i državna potrošnja.

Što se tiče srednje-tehnoloških komponenti industrijske proizvodnje, rezultati su pokazali da je utjecaj relativnih proizvođačkih cijena značajan s negativnim predznakom na razini od jedan posto signifikantnosti, odnosno porast relativnih proizvođačkih cijena djelovat će na smanjenje srednjo-tehnoloških komponenti industrijske proizvodnje. Od fiskalnih varijabli za ovu skupinu komponenti industrijske proizvodnje jedino se državna

\footnotetext{
${ }^{10}$ Prema $\mathrm{H}_{0} \rightarrow$ razlike između FE i RE procijena nisu signifikantne $\rightarrow$ bira se model stohastičkih efekata (random effects model). Prema $\mathrm{H}_{1}$ razlike između FE i $\mathrm{RE}$ jesu signifikantne $\rightarrow$ bira se model fiksnih efekata (fixed effects model). $\mathrm{U}$ ovom slučaju $\mathrm{H}_{0}$ se ne odbacuje jer su razlike između FE i RE procjena signifikantne (p-vrijednost $>$ $\alpha=0,05)$.
} 
potrošnja pokazala značajnom, i to na razini signifikantnosti od jedan posto. Ujedno je i pozitivan efekt državne potrošnje na industrijsku proizvodnju najveći. Potrošnja kućanstva i strana potražnja nisu se pokazale značajnima za razdoblje od 2000. do 2015. godine, nemaju utjecaj na srednje-tehnološke komponente industrijske proizvodnje. Što se tiče monetarnih varijabli, utjecaj kamatnih stopa na srednje-tehnološke komponente industrijske proizvodnje pokazao se pozitivno značajan na razini signifikantnosti od jedan posto $\mathrm{s}$ ne prevelikim efektom. S druge strane relativan tečaj ne utječe značajno na srednje-tehnološke komponente industrijske proizvodnje, te je predznak pozitivan, odnosno suprotan u odnosu na procjene za nisko-tehnološke i visoko-tehnološke komponente industrijske proizvodnje.

$\mathrm{Na}$ nisko-tehnološke komponente industrijske proizvodnje opet $\mathrm{s}$ negativnim predznakom relativne cijene industrijske proizvodnje imaju značajan utjecaj na razini signifikantnosti od jedan posto. Od fiskalnih varijabli najveći utjecaj na nisko-tehnološke komponente industrijske proizvodnje na razini signifikantnosti od jedan posto ima državna potrošnja s najvećim pozitivnim efektom. Uz državnu potrošnju značajnom na razini signifikantnosti od jedan posto pokazala se i domaća potrošnja, ali s negativnim predznakom što znači da će povećanje osobne potrošnje djelovati na smanjenje niskotehnoloških komponenti industrijske proizvodnje. Također, strana potražnja se pokazala značajnom na razini od deset posto signifikantnosti s očekivanim pozitivnim predznakom. Obje monetarne varijable pokazale su se značajnima, relativni tečaj na razini od deset posto s negativnim predznakom, a kamatne stope na razini od pet posto signifikantnosti s pozitivnim predznakom i minimalnim efektom.

Tablica 4. Panel analiza utjecaja monetarnih i fiskalnih mjera na industrijsku proizvodnju za razdoblje prije trećeg kvartala 2009. i nakon trećeg kvartala 2009. godine (random effects)

\begin{tabular}{|l|l|l|}
\hline \multicolumn{3}{|c|}{$\begin{array}{c}\text { Zavisna varijabla } \\
\text { IND_PPI }\end{array}$} \\
\hline Kontrolne varijable & prije 1q 2009.godine & nakon 1q 2009. godine \\
& & \\
\hline REL_PPI & $-0,67(0,09) * * *$ & $1,04(0,12) * * *$ \\
\hline C & $0,25(0,13) *$ & $-0,43(0,38)$ \\
\hline G & $0,27(0,09)$ & $1,26(0,58) * *$ \\
\hline GDP_F & $-0,02(0,28)$ & $-0,38(0,41)$ \\
\hline REER & $0,48(0,36)$ & $1,34(0,91)$ \\
\hline MM_IR & $-0,01(0,003)$ & $0,02(0,01) * *$ \\
\hline Diagnostics & & \\
\hline Number of observations & -760 & -621 \\
\hline Within $R$-squared & 0,1449 & 0,1785 \\
\hline Between $R$-squared & 0,1540 & 0,4341 \\
\hline Overall R-squared & 0,1441 & 0,2483 \\
\hline
\end{tabular}

Napomena: $* * *$ označava signifikantnost pri $1 \%, * *$ pri $5 \%$, a $*$ pri $10 \%$.

Izvor: izrada autora prema podacima DZS-a, Eurostata i Ministarstva financija. 
Obzirom da je utjecaj na industrijsku proizvodnju imala i jaka gospodarska kriza koja se s područja SAD-a prebacila na zemlje Europe, a tako i na Hrvatsku početkom 2009. godine panel je procijenjen u dva razdoblja te se rezultati mogu vidjeti u tablici 4. U tu svrhu procijenjena su dva panela, prije i nakon 1 tromjesečja 2009. godine. Prvo tromjesečje 2009 godine zabilježilo je najveći realni pad BDP-a u razdoblju od deset godina, što je jasno dalo naslutiti da su se efekti svjetske gospodarske krize osjetili i u Republici Hrvatskoj. Štoviše, sve kategorije BDP-a s rashodne strane zabilježile su značajan realni pad, a izdaci za potrošnju kućanstava, najveća kategorija u BDP-u, ostvarile su najveći realni pad u cijelome promatranom razdoblju do tada.

$\mathrm{U}$ svrhu analize razdoblja prije krize i nakon krize proučavanje utjecaj monetarnih i fiskalnih politika na ukupnu industrijsku proizvodnju, odnosno dvadeset $\mathrm{i}$ tri komponente industrijske proizvodnje bez podjele prema tehnološkom intenzitetu. Što se tiče razdoblja do prvog tromjesečja 2009. godine signifikantnim na razini od deset posto pokazao se samo utjecaj potrošnje kućanstva. Odnosno u skladu s teorijom povećanje potrošnje kućanstva djelovat će na povećanje industrijske proizvodnje. Također, bitno je naglasiti da se negativan utjecaj relativnih proizvođačkih cijena pokazao značajnim na razini od jedan posto.

U drugom promatranom razdoblju, od prvog tromjesečja 2009. pa nadalje, odnosno od službenog početka gospodarske krize u Republici Hrvatskoj od fiskalnih varijabli državna potrošnja pozitivno utječe na industrijsku proizvodnju te je značajna na razini signifikantnosti od pet posto, dok je od monetarnih odrednica na razini signifikantnosti od pet posto značajan utjecaj kamatnih stopa. Međutim, bitno je naglasiti da nakon službenog početka gospodarske krize u Republici Hrvatskoj relativne proizvođačke cijene pozitivno utječu na industrijsku proizvodnju na razini od jedan posto signifikantnosti, odnosno povećanje relativnih proizvođačkih cijena dovodi do povećanja industrijske proizvodnje u Republici Hrvatskoj.

Također, kako bi analiza bila što konzistentnija provedena je i panel analiza utjecaja monetarnih i fiskalnih mjera na industrijsku proizvodnju prema stupnju tehnološkog intenziteta za razdoblje prije nastupanja krize i nakon nastupanja krize $u$ Republici Hrvatskoj. Rezultati se razlikuju ovisno o kojim se komponentama industrijske proizvodnje radi. Za razdoblje prije prvog tromjesečja, utjecaj relativnih proizvođačkih cijena je signifikantan, ali s negativnim predznakom za sve tri skupine industrijske proizvodnje. Što se tiče visoko-tehnoloških komponenti industrijske proizvodnje za razdoblje prije nastupanja krize potrošnja kućanstva pokazala se pozitivno značajnom na razini od jedan posto. S druge strane, nakon prvog tromjesečja 2009. godine jedino su relativne proizvođačke cijene s negativnim predznakom imale utjecaj na ovu skupinu komponenti industrijske proizvodnje.

S druge strane, državna potrošnja i realni tečaj imaju najveći utjecaj na srednjetehnološke komponente industrijske proizvodnje za razdoblje prije nastupanja krize u Republici Hrvatskoj. Međutim, u razdoblju nakon prvog tromjesečja značajnim se i dalje pokazao tečaj, ali i strana potražnja s negativnim predznakom. Prema danim rezultatima, utjecaj monetarne i fiskalne politike veći je nakon nastupanja krize za nisko-tehnološke komponente industrijske proizvodnje. Iako su se prije nastupanja krize s negativnim predznakom značajnima pokazale jedino relativne proizvođačke cijene, nakon nastupanja 
krize na nisko tehnološke komponente značajno utječe potrošnja kućanstva, ali $\mathrm{s}$ negativnim predznakom što nije u skladu s literaturom te pozitivno utječe državna potrošnja.

Tablica 5. Panel analiza utjecaja monetarnih i fiskalnih mjera na industrijsku proizvodnju prema stupnju tehnološkog intenziteta za razdoblje prije prvog tromjesečja 2009. (random effects)

\begin{tabular}{|c|c|c|c|}
\hline \multicolumn{4}{|c|}{$\begin{array}{c}\text { Zavisna varijabla } \\
\text { IND_PPI (razdoblje prije 1Q2009) }\end{array}$} \\
\hline Kontrolne varijable & $\begin{array}{c}\text { visoko- } \\
\text { tehnološke } \\
\text { komponente } \\
\text { industrijske } \\
\text { proizvodnje }\end{array}$ & $\begin{array}{c}\text { srednje- } \\
\text { tehnološke } \\
\text { komponente } \\
\text { industrijske } \\
\text { proizvodnje }\end{array}$ & $\begin{array}{l}\text { nisko tehnološke } \\
\text { komponente } \\
\text { industrijske } \\
\text { proizvodnje }\end{array}$ \\
\hline REL PPI & $0,66(0,17) * * *$ & $-0,77(0,07) * * *$ & $-1,24(0,19) * * *$ \\
\hline $\mathrm{C}$ & $0,85(0,24) * * *$ & $0,15(0,19)$ & $-0,01(0,20)$ \\
\hline $\mathrm{G}$ & $0,41(1,16)$ & $1,02(0,46) * *$ & $0,15(0,47)$ \\
\hline GDP F & $-0,28(0,52)$ & $0,14(0,41)$ & $0,05(0,42)$ \\
\hline REER & $0,45(0,66)$ & $2,29(0,53) * * *$ & $-0,69(0,56)$ \\
\hline MM_IR & $-0,01(0,01)$ & $0,0002(0,004)$ & $0,001(0,004)$ \\
\hline \multicolumn{4}{|l|}{ Diagnostics } \\
\hline Number of observations & 231 & 165 & 364 \\
\hline Within $R$-squared & 0,2888 & 0,5114 & 0,0952 \\
\hline Between $R$-squared & 0,0741 & 0,8860 & 0,5445 \\
\hline Overall R-squared & 0,0739 & 0,6010 & 0,3845 \\
\hline
\end{tabular}

Napomena: *** označava signifikantnost pri $1 \%$, ** pri $5 \%$, a $*$ pri $10 \%$.

Izvor: izrada autora prema podacima DZS-a, Eurostata i Ministarstva financija. 
Tablica 6. Panel analiza utjecaja monetarnih i fiskalnih mjera na industrijsku proizvodnju prema stupnju tehnološkog intenziteta za razdoblje nakon prvog tromjesečja 2009. (random effects)

\begin{tabular}{|l|l|l|l|}
\hline \multicolumn{4}{|c|}{$\begin{array}{c}\text { Zavisna varijabla } \\
\text { IND_PPI (razdoblje nakon 1Q2009) }\end{array}$} \\
\hline Kontrolne varijable & $\begin{array}{c}\text { visoko- } \\
\text { tehnološke } \\
\text { komponente } \\
\text { industrijske } \\
\text { proizvodnje }\end{array}$ & $\begin{array}{c}\text { srednje- } \\
\text { tehnološke } \\
\text { komponente } \\
\text { industrijske } \\
\text { proizvodnje }\end{array}$ & $\begin{array}{c}\text { nisko tehnološke } \\
\text { komponente } \\
\text { industrijske } \\
\text { proizvodnje }\end{array}$ \\
\hline REL_PPI & $2,08(0,22) * * *$ & $-0,22(0,17)$ & $1,06(0,24) * * *$ \\
\hline C & $0,51(0,75)$ & $0,17(0,64)$ & $-1,37(0,50) * * *$ \\
\hline G & $0,41(1,16)$ & $1,21(0,99)$ & $1,45(0,78) *$ \\
\hline GDP_F & $-0,28(0,80)$ & $-1,50(0,69) * *$ & $0,23(0,55)$ \\
\hline REER & $-0,02(1,82)$ & $2,76(1,56) *$ & $0,31(1,23)$ \\
\hline MM_IR & $0,02(0,02)$ & $0,007(0,013)$ & $0,02(0,01)$ \\
\hline & & & \\
\hline Diagnostics & & 135 & 297 \\
\hline Number of observations & 189 & 0,1257 & 0,1512 \\
\hline Within $R$-squared & 0,4034 & 0,3616 & 0,4133 \\
\hline Between $R$-squared & 0,7999 & 0,1284 & 0,1843 \\
\hline Overall R-squared & 0,5664 & $10 \%$ & \\
\hline
\end{tabular}

Napomena: $* * *$ označava signifikantnost pri $1 \%$, ** pri $5 \%$, a $*$ pri $10 \%$.

Izvor: izrada autora prema podacima DZS-a, Eurostata i Ministarstva financija.

\section{ZAKLJUČAK}

Cilj ovog rada bio je istražiti kako monetarna i fiskalna politika, odnosno makroekonomske odrednice utječu na industrijsku proizvodnju u Republici Hrvatskoj. Empirijskom analizom pokazano je na koji način makroekonomske politike, odnosno makroekonomske odrednice utječu na komponente industrijske proizvodnje grupirane prema stupnju tehnološkog intenziteta, te kakav je utjecaj makroekonomskih odrednica na ukupnu industrijsku proizvodnju prije i nakon nastupa gospodarske krize u Republici Hrvatskoj 2009. godine. Rezultati pokazuju da i monetarna i fiskalna politika značajno određuju smjer kretanja industrijske proizvodnje.

Relativne proizvođačke cijene utječu na sve komponente industrijske proizvodnje bez obzira na stupanj tehnološkog intenziteta. Međutim, efekt relativnih proizvođačkih cijena pozitivan je samo za visoko-tehnološke komponente industrijske proizvodnje, dok na srednjo-tehnološke i nisko-tehnološke komponente industrijske proizvodnje relativne proizvođačke cijene utječu s negativnim predznakom. Također, bitno je naglasiti da su prije nastupanja gospodarske krize u Republici Hrvatskoj, 
relativne proizvođačke cijene utjecale $\mathrm{s}$ negativnim predznakom na industrijsku proizvodnju, dok je nakon krize taj efekt pozitivan i veći. Što se tiče fiskalnih i monetarnih odrednica, državna potrošnja i kamatne stope imaju značajan utjecaj na sve komponente industrijske proizvodnje bez obzira na stupanj tehnološkog intenziteta. Posebno se ističe pozitivan efekt državne potrošnje na sve tri grupe komponenti industrijske proizvodnje koji se osim kod grupiranja pokazao i u drugom dijelu analize značajnim te s pozitivnim efektom nakon nastupanja gospodarske krize, 2009. godine. Efekt kamatnih stopa pokazao se nesignifikantnim, ali s negativnim predznakom prije nastupanja krize, dok nakon nastupanja krize porast kamatnih stopa djeluje na povećanje industrijske proizvodnje.

Uzimajući u obzir kako je već dugi niz godina prisutna usredotočenost na učinak potencijalne deprecijacije tečaja na industrijsku proizvodnju i izvoz, te kako je za očekivati da deprecijacija realnog efektivnog tečaja dovodi do povećanja izvoza, posebno u izvozno orijentiranim zemljama, u empirijsku analizu uključen je i realni efektivni tečaj koji se pokazao značajnim jedino za komponente industrijske proizvodnje niskogtehnološkog intenziteta. Također, predznak je u skladu s teorijom odnosno deprecijacija realnog efektivnog tečaja dovest će do povećanja nisko-tehnoloških komponenti industrijske proizvodnje. Međutim, realni efektivni tečaj se pokazao nesignifikantnim za razdoblje prije i nakon krize, te pozitivnog predznaka što se može objasniti činjenicom da je Hrvatska visoko euroizirana ekonomija, s proizvodnim poduzećima zaduženima u stranoj valutnoj klauzuli te s velikim uvoznim inputima u proizvodnji roba.

Empirijska analiza pokazuje kako industrijska proizvodnja koju u analizi čine dvadeset $\mathrm{i}$ tri komponente grupirane prema stupnju tehnološkog intenziteta reagira $\mathrm{i}$ na monetarne i na fiskalne odrednice. To dovodi do zaključka kako je za održivu i stabilnu industrijsku proizvodnju potrebna koordinacija monetarne i fiskalne politike. Međutim, mjere monetarne i fiskalne politike nisu dovoljne za rješavanje svih problema $\mathrm{u}$ industrijskoj proizvodnji. Ukoliko se želi povećati uspješnost i poboljšati struktura industrijske proizvodnje, potrebne su i adekvatne tehnološke promjene i transferi, promicanje inovacija, stranih izravnih ulaganja te poticanje konkurencije među samim komponentama industrijske proizvodnje.

\section{LITERATURA:}

1. Adam, C. S., Bevan, D. L., \& Chambas, G. (2001). Exchange rate regimes and revenue performance in Sub-Saharan Africa. Journal of Development Economics, 64(1), 173-213.

2. Asteriou, D., \& Hall, S. G. (2007). Applied Econometrics: a modern approach, revised edition. Hampshire: Palgrave Macmillan, 46(2), 117-155.

3. Barro, R. J. (1991). Economic growth in a cross section of countries. The quarterly journal of economics, 106(2), 407-443.

4. Bruce, N., \& Turnovsky, S. J. (1999). Budget balance, welfare, and the growth rate:" dynamic scoring" of the long-run government budget. Journal of Money, Credit, and Banking, 162-186. 
5. Campa, J., \& Goldberg, L. S. (1997). The evolving external orientation of manufacturing industries: evidence from four countries (No. w5919). National Bureau of Economic Research.

6. Ćorić, T., Šimović, H., \& Deskar-Škrbić, M. (2015.). Monetarna i fiskalna politika miješaju se u malo otvoreno gospodarstvo: slučaj Hrvatske. Ekonomska istraživanja, 28(1), 407-421.

7. Erjavec, N., Cota, B., \& Bahovec, V. (1999). Monetarno-kreditna i realna privredna aktivnost u Republici Hrvatskoj: VAR model. Ekomomski pregled, 50(11), 1488-1504.

8. European Commission, 2009.a, European Competitiveness Report 2008, Luxembourg: European Commission.

9. Ezeaku, H. C., Ibe, I. G., Ugwuanyi, U. B., Modebe, N. J., \& Agbaeze, E. K. (2018). Monetary policy transmission and industrial sector growth: Empirical evidence from Nigeria. Sage Open, 8(2), 2158244018769369.

10. Fischer, S. (1993). The role of macroeconomic factors in growth. Journal of monetary economics, 32(3), 485-512.

11. Kormendi, R. C., \& Meguire, P. G. (1985). Macroeconomic determinants of growth: Cross-country evidence. Journal of Monetary economics, 16(2), 141163.

12. Kutu, A. A., Nzimande, N. P., \& Msomi, S. (2017). Effectiveness of Monetary Policy and the Growth of Industrial Sector in China. Journal of Economics and Behavioral Studies, 9 (3 (J)), 46-59.

13. Levine, R., \& Renelt, D. (1992). A sensitivity analysis of cross-country growth regressions. The American economic review, 942-963.

14. Shobande, O. A. (2019). Monetary Policy Spillovers Through Industrial Growth in Nigeria: A Time Series Analysis. Economics and Business, 33(1), 94-110.

15. Tkalec, M., \& Vizek, M. (2009). The impact of macroeconomic policies on manufacturing production in croatia. Privredna kretanja i ekonomska politika, 19(121), 61-93.

16. Vizek, M. (2008). Econometric analysis of monetary transmission channels in Croatia. Croatian Economic Survey, (10), 11-44. 


\title{
THE IMPACT OF MONETARY AND FISCAL POLICY ON INDUSTRIAL PRODUCTION IN CROATIA
}

\section{Petra Palić}

\begin{abstract}
Summary
This paper investigates the impact of monetary and fiscal policy on industrial production in Croatia. Numerous foreign and domestic studies have estimated this relationship with the aim of making recommendations to economic policy makers. Using the panel model, it examines how relative producer prices, government consumption, personal consumption, interest rates, real effective exchange rate and foreign demand affect 23 components of industrial production according to the level of the technological intensity. The analysis is conducted on quarterly data for the period from the first quarter of 2000 to the last quarter of 2015. Also, an analysis of the impact of monetary and fiscal policy on industrial production for the period before and after the economic crisis in the Republic of Croatia is conducted. The results of the empirical part of the research are in accordance with the domestic and foreign literature, and a statistically significant relationship between the impact of monetary and fiscal policy on industrial production is noticed.
\end{abstract}

Keywords: industrial production; fiscal policy; monetary policy; panel analysis. 